\title{
Ryan Szpiech \\ Conversion and Narrative: Reading and Religious Authority \\ in Medieval Polemic
}

(Philadelphia: University of Pennsylvania Press, 2013), hardcover, 311 pp.

\author{
ORA LIMOR \\ orali@openu.ac.il \\ The Open University of Israel, Ra'anana, 4353701, Israel
}

Within the large body of polemical works written in the Middle Ages by Christian, Jewish, and Muslim authors, especially compelling and powerful are autobiographical conversion narratives written for polemical or apologetic aims. These conversion narratives are the subject of Ryan Szpiech's impressive book, Conversion and Narrative. Such accounts often appear at the opening of polemical works, describe the circumstances of the author's conversion, and attempt to establish his authority by citing his personal experience and his lingual and textual knowledge of the texts of his former religion. Szpiech aims to show that there is a fundamental connection between conversion stories and medieval polemical writings and to understand their usefulness in presenting polemical arguments. $\mathrm{He}$ also seeks to explore the reasons for the reappearance of conversion stories from the twelfth century onwards, and to contextualize the importance of Christian conversion narratives by comparing them to Jewish and Muslim ones. Szpiech achieves these aims in a most powerful way through a close reading of his sources and meticulous analysis.

Following Karl Morrison, Szpiech stresses the elusive quality of the term "conversion." Conversion, he writes, "is a collective representation that can be used for convenience but whose full range of significance is perpetually deferred and never definitely grasped" (pp. 16-17). He distinguishes between conversion and stories about conversion and sees the latter as "a category of discourse" (p. 6), criticizing the aspiration to reach the "real" convert that hides behind the protagonist of the conversion narrative (p. 19). From among the vast corpus of conversion narratives, Szpiech chooses only those with an explicitly polemical thrust. This results in a certain homogeneity of source material, privileging learned and theological writings with a didactic aim written by male protagonists.

Szpiech focuses on, among others, convert authors such as Moses / Petrus Alfonsi (early twelfth century), Judah / Herman of Cologne (mid-twelfth century), Abner of Burgos / Alfonso de Valladoid (d. ca. 1347), Solomon Halevi / 
Pablo de Santa María (d. 1435), Giuàn / Obadiah ha-Ger (twelfth century), and Abd Allah / Juan Andrés (d. sixteenth century). By retaining throughout the book his protagonists' pre- and post-conversion names, Szpiech fixes firmly for his readers the hybridity of the converts' personae. Rather than being simply former Jews or new Christians, they assume a special, third identity: the convert. This is a strong analytical tool, although we can assume that the converts themselves would prefer to be called solely by their new name, the one that signifies their new identity and the radical choice they had made.

The conversion narratives dealt with in the book recount personal journeys of faith, with all their attendant psychological struggles. The "narrative drama" of these literary accounts (p. 10) and religious polemics are intertwined in these texts in various ways, and Szpiech skillfully disentangles this drama and exposes its power. The innovation of Conversion and Narrative lies in its reading of these narrations as literary constructs rather than as historical accounts. The "facticity" of the stories is of negligible importance for Szpiech (p. 18). What interests him are the modes of authority found in conversion stories, which are built upon the converts' claim to "authenticity" stemming from personal experience (e.g., p. 90).

The book is comprised of a theoretical introduction followed by six chapters. The first chapter deals with two fifteenth-century accounts of converts to Christianity, Juan Andrés and Solomon Halevi / Pablo de Santa María. Here, Szpiech examines how Pauline and Augustinian conversion paradigms remained the template of all conversion narratives and how they were adapted and transformed with time. The second chapter returns to the twelfth century to deal with Christian notions of textual authority through the anti-Jewish book of Moses / Petrus A1fonsi and the autobiographical narrative of Judas / Herman of Cologne. Szpiech strives to understand the appearance at that time of the new polemical genrepersonal narratives of conversion - as a kind of response to a crisis in the understanding of the notion of textual auctoritas. These narratives sought to establish the protagonists' authority in both their former and newly adopted faiths by demonstrating their personal struggles. The third chapter turns to several examples of conversion to Judaism. Szpiech claims convincingly that the accounts of Bodo / Eleazar (ninth century) and Wecelinus (eleventh century) can be read only within a Christian conceptual frame, and even the Genizah narrative of Giuàn / Obadiah ha-Ger "seems to be informed by a Christian model of narrating conversion" (p. 115). In the following chapter Szpiech analyzes thirteenth-century notions of authority and authenticity in the works of two famous polemicists, the Dominican Ramon Martí, who put much weight on the importance of the original languages of his (often Jewish) sources, and the "self-made convert" Ramon Lull, who chose reason as his main polemical tool (p. 134). Although very different from each other, both Lull and Martí were concerned with the construction of their authority. As Szpiech writes, "the recognition of non-Christian authority first pursued by Martí as the foundation of Christian apology would become a standard of Western Christian argumentation" (p. 141).

Chapter five of the book deals with the ways in which the fourteenth-century Jewish convert to Christianity Abner of Burgos / Alfonso of Valladolid fashioned 
his authority. Szpiech shows how Abner / Alfonso's conversion account, situated at the start of his work, defined his very identity for posterity, and how in his hands such accounts became the quintessential polemical device. This combination of personal experience (including the series of dreams he experienced) and religious knowledge forms Abner / Alfonso's authoritative voice and determines its strength. "In his writings," notes Szpiech, "the threads of the twelfth and thirteenth centuries are braided into a single chain of textual authority and authorial voice" (p. 166). This chapter is the strongest in a strong book, and can be considered its most original contribution to the field. Personally, I would have been glad to see more direct citations from Abner / Alfonso's works that would demonstrate the qualities of the account, so well analyzed by Szpiech. (More direct citations would be welcome in other chapters of the book as well.)

The last chapter presents four stories of conversion to Islam, comparing them to the Christian examples treated earlier. The most notable of these are the stories of the former Jew Samaw'al al-Maghribī (thirteenth century) and the exFranciscan Anselm Turmeda / 'Abd Allāh al-Turjumān (fifteenth century). Both adopt a supersessionist ideology that sees in Islam a final truth that encapsulates and surpasses the former faiths. The inclusion of Jewish and Muslim texts permits a multi-cultural perspective on the topic, although, as the author asserts, the model of all these conversion stories remains Christian, and the conversions stories of Saul / Paul and especially of Augustine underly "both the imagery and the conceptualization of conversion" in Christian as well as in non-Christian sources.

Szpiech is not interested in the reception of the texts, their readers, their influence, or the impact they had (or did not have). These are all questions he leaves to historians of polemics. He also refrains from delving into the polemical arguments used in his sources, because, as he rightly asserts, while the arguments are common and even at times formulaic, the narrative elaborations in many of his sources are not. The book offers an insightful reading of these narrative elaborations. While it is charged with theoretical discussions within the categories of literary criticism that may not be as familiar to historians of polemics, it is worth the effort. In Szpiech's own words, "Conversion stories function as a sort of shorthand of belief, summing up an entire theology of history in a single symbolic gesture of faith" (p. 219). 